Phosphorus Research Bulletin Vol. 33 (2017) pp. 021-025

\title{
INTRODUCTION OF PHOSPHATE GROUP INTO $\beta$-ARBUTIN BY CYCLO-TRIPHOSPHATE
}

\author{
Hideko Maeda $^{1 *}$, Mako Katsushiro ${ }^{1}$, \\ Hiroyuki Nariai ${ }^{2}$, Hirokazu Nakayama ${ }^{1}$ \\ (i-hideko@kobepharma-u.ac.jp)

\begin{abstract}
${ }^{1}$ Department of Functional Molecular Chemistry, Kobe Pharmaceutical University, 4-19-1 Motoyamakita-machi, Higashinada-ku, Kobe 658-8558 Japan.

${ }^{2}$ Department of Chemical Science and Engineering, Faculty of Engineering, Kobe University, 1-1 Rokkodai-cho,
\end{abstract} \\ Nada-ku, Kobe 657-8501 Japan.
}

Keywords: Phosphorylation; $\beta$-Arbutin; cyclo-Triphosphate; HPLC; ${ }^{31}$ P NMR

Abstract: Phosphorylation of $\beta$-arbutin has been achieved using inorganic cyclo-triphosphate $\left(\mathrm{P}_{3 \mathrm{~m}}\right)$ in aqueous solution. The optimum condition for the phosphorylation of $\beta$-arbutin with $\mathrm{P}_{3 \mathrm{~m}}$ is $\beta$-arbutin : $\mathrm{P}_{3 \mathrm{~m}}=0.1 \mathrm{~mol} / \mathrm{L}: 0.5 \mathrm{~mol} / \mathrm{L}$, $\mathrm{pH} 11$ and $40^{\circ} \mathrm{C}$. 4-Triphospho- $\beta$-arbutin was synthesized with the yield of $90 \%$. The reaction mechanism of $\beta$-arbutin with $\mathrm{P}_{3 \mathrm{~m}}$ was discussed. We have successfully introduced the triphosphate group in one molecule. Phosphorylated $\beta$-arbutin is expected that the permeability of $\beta$-arbutin into the skin will be increased by introducing a phosphate group.

(Received Jul 7, 2017; Accepted Aug 2, 2017)

\section{INTRODUCTION}

$\beta$-Arbutin (4-hydroxyphenyl- $\beta$-D-glucopyrano side) is found in the leaves of bearberry, blueberry, and pear trees ${ }^{1}$. It inhibits melanin synthesis by inhibition of tyrosinase activity ${ }^{2,3}$. Therefore, $\beta$-arbutin is blended to cosmetics as a skin lighting agent ${ }^{4}$. It has also been reported that it has a diuretic action and a urinary tract sterilizing action, and it is regarded as a urinary tract antiseptic ${ }^{5}$. However, the usage is restricted because of its poor water solubility. $\beta$-Arbutin is expected to possess higher solubility by the introduction of phosphoryl group.

Duarte et al. ${ }^{6}$ reported that L-ascorbyl2-phosphate introduced to phosphate group in L-ascorbic acid was non-toxic vitamin $\mathrm{C}$ analogue. Kameyama and coworkers indicated that L-ascorbyl2-phosphate was absorbed percutaneously and retained in the $\operatorname{skin}^{7}$. Kobayashi et al. demonstrated that L-ascorbyl-2-phosphate was hydrolyzed and converted to ascorbic acid by acidic phosphatase in lysosomes and alkaline phosphatase in the serum ${ }^{8}$. Then, phosphorylated $\beta$-arbutin is expected that the permeability of $\beta$-arbutin into the skin will be increased by introducing a phosphate group.

As shown in Fig. 1, sodium cyclo-triphosphate, $\mathrm{Na}_{3} \mathrm{P}_{3} \mathrm{O}_{9} \quad\left(\mathrm{P}_{3 \mathrm{~m}}\right)$ is triphosphate with six-membered ring structure. $\quad \mathrm{P}_{3 \mathrm{~m}}$ has been used for phosphorylating agent since Quimby and Flautt ${ }^{9}$ produced amidotriphosphate in 1958. Because of its unique structure, biologically important compounds having an amino or a hydroxyl group can be phosphorylation by $\mathrm{P}_{3 \mathrm{~m}}{ }^{10,11}$. Also, the phosphorylation reactions were proceeded in aqueous solution by one-step.

In this study, we examined the phosphorylation reaction of $\beta$-arbutin and $\mathrm{P}_{3 \mathrm{~m}}$ to synthesize a novel $\beta$-arbutin containing phosphate groups.<smiles>O=P1(O[Na])OP(=O)(O[Na])OP(=O)(O[Nb])O1</smiles>

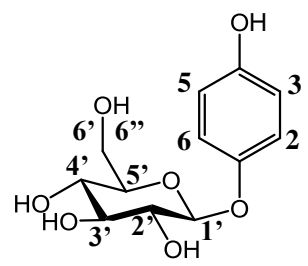
sodium cyclo-triphosphate
$\left(\mathbf{P}_{3 \mathrm{~m}}\right)$

FIGURE 1 Structures of sodium cyclo-triphosphate $\left(\mathrm{P}_{3 \mathrm{~m}}\right)$ and $\beta$-arbutin

\section{EXPERIMENTAL}

\section{Materials and methods}

Sodium cyclo-triphosphate $\left(\mathrm{Na}_{3} \mathrm{P}_{3} \mathrm{O}_{9}, \mathrm{P}_{3 \mathrm{~m}}\right)$ was purchased from BK Giulini (Ludwigshafen, German). Sodium 2,2-dimethyl-2-silapentane-5-sulfonate (DSS) was purchased from Sigma-Aldrich Chemical Co. (St. Louis, USA). $\quad \beta$-Arbutin and other reagents were purchased from Tokyo Kasei Chemicals (Tokyo, Japan) and Wako Pure Chemical Industries, Ltd. (Osaka, Japan), respectively.

HPLC analysis was performed on a JASCO 
PU-2080i system (JASCO, Tokyo, Japan), using a InertSustain C18 column $(250 \times 6.0 \mathrm{~mm}$ i.d., $5 \mu \mathrm{m}$, GL Science, Tokyo, Japan) maintained at $40{ }^{\circ} \mathrm{C}$. Isocratic elution using a 20:80 (v/v) methanol/ $\mathrm{H}_{2} \mathrm{O}$ solution was employed at a flow rate of $0.25 \mathrm{ml} / \mathrm{min}$ with UV detection at $254 \mathrm{~nm}$. The amount of sample injected was $100 \mu \mathrm{L}$. The system control, data collection, and data analysis were carried out by JASCO-ChromNAV system (Version 1.18. 03, JASCO, Tokyo, Japan).

${ }^{31} \mathrm{P}$ NMR spectra with and without broad band ${ }^{1} \mathrm{H}$ decoupling and ${ }^{31} \mathrm{P}_{-}{ }^{1} \mathrm{H}$ heteronuclear multiple bond correlation spectroscopy (HMBC), and ${ }^{1} \mathrm{H}-{ }^{1} \mathrm{H}$ correlation spectroscopy (COSY) 2D NMR spectra were obtained with a Bruker Ascend $600 \mathrm{MHz}$ NMR spectrometer (Billerica of Massachusetts, USA) using $85 \% \mathrm{H}_{3} \mathrm{PO}_{4}$ solution in $\mathrm{D}_{2} \mathrm{O}$ as an external standard.

Electrospray ionization mass spectrometry (ESI-MS) was performed using a Thermo Scientific Exactive ${ }^{\mathrm{TM}}$ mass spectrometer (Thermo Fisher Scientific, Commonwealth of Massachusetts, USA). The mass spectrometer was operated in a negative-ion mode.

\section{RESULTS AND DISCUSSION}

\section{Reaction of $\beta$-arbutin with $P_{3 m}$}

The phosphorylation of $\beta$-arbutin with $\mathrm{P}_{3 \mathrm{~m}}$ was performed in aqueous solution. Figure 2 shows the HPLC profiles for the reaction solution of $\beta$-arbutin $(0.1 \mathrm{~mol} / \mathrm{L})$ and $\mathrm{P}_{3 \mathrm{~m}}(0.5 \mathrm{~mol} / \mathrm{L})$ incubated at $\mathrm{pH} 11$ at $40{ }^{\circ} \mathrm{C}$.

The peaks at a retention time of about $9 \mathrm{~min}$ increased gradually with reaction time, predicting the product of $\beta$-arbutin. From the results of NMR and MS data as described later, the peaks at 9 min were found to be 4 -triphospho- $\beta$-arbutin (product) and the peaks at $11 \mathrm{~min}$ were by-product. Although by-product could not be identified only by HPLC, it was found to be diphospho- or monophospho$\beta$-arbutin ${ }^{12}$. The other chromatographic peaks at 14 min were assigned to $\beta$-arbutin.

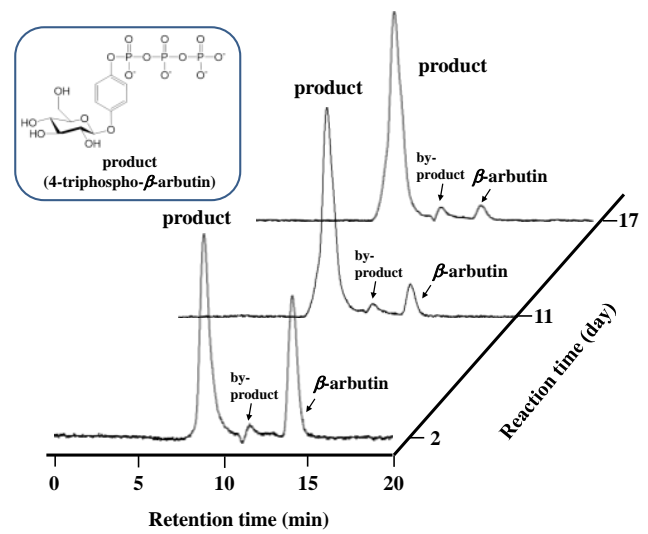

FIGURE 2 HPLC profiles of the reaction solution of $\beta$-arbutin $(0.1 \mathrm{~mol} / \mathrm{L})$ with $\mathrm{P}_{3 \mathrm{~m}}(0.5 \mathrm{~mol} / \mathrm{L})$ at $\mathrm{pH}$ 11 and $40{ }^{\circ} \mathrm{C}$
The yield of 4-triphospho- $\beta$-arbutin increased gradually with reaction time to reach the maximum of $94 \%$ after 17 days. The yield remained constant until $25 \mathrm{~d}$ and that of by-product did not increase.

Table 1 summarizes the yield of 4-triphospho$\beta$-arbutin under various reaction conditions. At 25 ${ }^{\circ} \mathrm{C}$ and $\mathrm{pH} 10$, the yield of product was 13,46 , and $57 \%$ in a molar ratio of $\beta$-arbutin : $\mathrm{P}_{3 \mathrm{~m}}=0.1 \mathrm{~mol} / \mathrm{L}$ : $0.1 \mathrm{~mol} / \mathrm{L}, 0.1 \mathrm{~mol} / \mathrm{L}: 0.3 \mathrm{~mol} / \mathrm{L}$, and $0.1 \mathrm{~mol} / \mathrm{L}: 0.5$ $\mathrm{mol} / \mathrm{L}$, respectively. The yield of product increased with the increase of initial concentration of $\mathrm{P}_{3 \mathrm{~m}}$. The solubility of $\mathrm{P}_{3 \mathrm{~m}}$ is $0.5 \mathrm{~mol} / \mathrm{L}$, therefore, a molar ratio of $\beta$-arbutin : $\mathrm{P}_{3 \mathrm{~m}}=0.1 \mathrm{~mol} / \mathrm{L}: 0.5 \mathrm{~mol} / \mathrm{L}$ is preferable.

At a molar ratio of $\beta$-arbutin : $\mathrm{P}_{3 \mathrm{~m}}=0.1 \mathrm{~mol} / \mathrm{L}$ : $0.5 \mathrm{~mol} / \mathrm{L}$ and $25^{\circ} \mathrm{C}$, the yield of product was $26 \%$ at

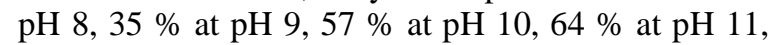
and $70 \%$ at $\mathrm{pH}$ 12. Although the yield of triphospho- $\beta$-arbutin improved as the $\mathrm{pH}$ increased, those of diphospho- or monophospho- $\beta$-arbutin also increased at $\mathrm{pH} 12$. Therefore, $\mathrm{pH} 11$ is preferable.

At a molar ratio of $\beta$-arbutin : $\mathrm{P}_{3 \mathrm{~m}}=0.1 \mathrm{~mol} / \mathrm{L}$ : $0.5 \mathrm{~mol} / \mathrm{L}$ and $\mathrm{pH} 11$, the yield of product was $51 \%$ at $10{ }^{\circ} \mathrm{C}, 67 \%$ at $25{ }^{\circ} \mathrm{C}$, and $94 \%$ at $40{ }^{\circ} \mathrm{C}$. Although the yield of triphospho- $\beta$-arbutin improved as the temperature increased, those of diphospho- or monophospho- $\beta$-arbutin also increased at $60{ }^{\circ} \mathrm{C}$. Therefore, preferable temperature is $40^{\circ} \mathrm{C}$.

Consequently, the optimum condition for the phosphorylation of $\beta$-arbutin with $\mathrm{P}_{3 \mathrm{~m}}$ is $\beta$-arbutin : $\mathrm{P}_{3 \mathrm{~m}}=0.1 \mathrm{~mol} / \mathrm{L}: 0.5 \mathrm{~mol} / \mathrm{L}, \mathrm{pH} 11$ and $40^{\circ} \mathrm{C}$.

TABLE 1 Yields of 4-triphospho- $\beta$-arbutin

\begin{tabular}{|c|c|c|c|c|c|}
\hline \multicolumn{5}{|c|}{ Reaction conditions } & \multirow{3}{*}{$\begin{array}{r}\text { Yield } \\
(\%)\end{array}$} \\
\hline \multicolumn{2}{|c|}{ Conc. (mol/L) } & \multirow{2}{*}{$\mathrm{pH}$} & \multirow{2}{*}{$\begin{array}{c}\text { Temp. } \\
\left({ }^{\circ} \mathrm{C}\right)\end{array}$} & \multirow{2}{*}{$\begin{array}{l}\text { Time } \\
\text { (d) }\end{array}$} & \\
\hline$\beta$-arbutin & $\mathrm{P}_{3 \mathrm{~m}}$ & & & & \\
\hline 0.1 & 0.1 & 10 & 25 & 27 & 13 \\
\hline 0.1 & 0.3 & 10 & 25 & 13 & 46 \\
\hline 0.1 & 0.5 & 10 & 25 & 23 & 57 \\
\hline \multirow{5}{*}{0.1} & 0.5 & 12 & 25 & 9 & 70 \\
\hline & & 11 & 25 & 10 & 64 \\
\hline & & 10 & 25 & 13 & 57 \\
\hline & & 9 & 25 & 24 & 35 \\
\hline & & 8 & 25 & 22 & 26 \\
\hline \multirow[t]{3}{*}{0.1} & 0.5 & 11 & 10 & 23 & 51 \\
\hline & & 11 & 25 & 17 & 67 \\
\hline & & 11 & 40 & 17 & 94 \\
\hline
\end{tabular}

The procedure for the isolation of 4-triphospho$\beta$-arbutin

Product (4-triphospho- $\beta$-arbutin) was synthesized by dissolving $\beta$-arbutin $(1.3613 \mathrm{~g}, 0.5 \mathrm{~mol} / \mathrm{L})$ and $\mathrm{P}_{3 \mathrm{~m}}$ ( $1.5294 \mathrm{~g}, 0.5 \mathrm{~mol} / \mathrm{L})$ in $\mathrm{H}_{2} \mathrm{O}(20 \mathrm{~mL})$ at $40{ }^{\circ} \mathrm{C}$, and adjusting the solution to $\mathrm{pH} 11$ by adding $6 \mathrm{M} \mathrm{NaOH}$ solution. After seven days, the yield of the 4-triphospho- $\beta$-arbutin due to the peak at $9 \mathrm{~min}$ by HPLC was $62 \%$. Then the reaction solution was 
adjusted to $\mathrm{pH}$ 7. Although the phosphorylated $\beta$-arbutin undergo hydrolysis to $\beta$-arbutin and triphosphate with the passage of time at $25{ }^{\circ} \mathrm{C}$ and high $\mathrm{pH}$, it is stable at $\mathrm{pH} 7$.

The separation of product was accomplished by anion-exchange chromatography on a $2 \times 80 \mathrm{~cm}$ column filled with Dowex 1-X2 resin (100-200 mesh, $\mathrm{Cl}^{-}$form). Elution was carried out with distilled water until no further $\beta$-arbutin appeared. Then elution was carried out with aqueous $0.3 \mathrm{~mol} / \mathrm{L} \mathrm{KCl}$. Fractions of $50 \mathrm{~mL}$ were collected during the elution process, and those fractions obtained during the volume range of 400 to $450 \mathrm{~mL}$ (during which the product was obtained) were analyzed via HPLC. Then, each fraction was concentrated via freeze-drying. For the purpose of desalting, an aqueous solution of the concentrate was passed over a PD-10 column (GE Healthcare UK Ltd, Little Chalfont, England). Each $0.5 \mathrm{~mL}$ fraction was measured by HPLC, and the fractionated solutions containing only 4-triphospho- $\beta$-arbutin was freeze-dried.

An aqueous solution of the concentration of 0.5 $\mathrm{mg} / \mathrm{mL}$ was measured by HPLC. 4-Triphospho- $\beta$-arbutin was $90 \%$ in purity. The ESI-MS spectrum of aliquot solution showed the molecular ion for the deprotonated 4-triphospho- $\beta$-arbutin.

4-Triphospho- $\beta$-arbutin : ${ }^{1} \mathrm{H}$ NMR $\left(\mathrm{D}_{2} \mathrm{O}\right) \quad \delta$ : 7.1695 (2H, m, H3, H5), 7.0415 (2H, m, H2, H6), $5.0085\left(1 \mathrm{H}, \mathrm{d}, J_{\mathrm{H} 1}{ }^{\prime}, \mathrm{H}{ }^{\prime},=7.8 \mathrm{~Hz}, \mathrm{H}-1^{\prime}\right), 3.4695(1 \mathrm{H}$, $\left.\mathrm{dd}, J_{\mathrm{H} 1^{\prime}, \mathrm{H} 2^{\prime}}=7.8 \mathrm{~Hz}, J_{\mathrm{H} 2^{\prime}, \mathrm{H} 3^{\prime}}=9.6 \mathrm{~Hz}, \mathrm{H}-2^{\prime}\right), 3.527$ $\left(1 \mathrm{H}, \mathrm{dd}, J_{\mathrm{H} 2^{\prime}, \mathrm{H} 3^{\prime}}=9.6 \mathrm{~Hz}, J_{\mathrm{H} 3^{\prime}, \mathrm{H} 4^{\prime}}=9.0 \mathrm{~Hz}, \mathrm{H}-3^{\prime}\right)$, $3.417\left(1 \mathrm{H}, \mathrm{dd}, J_{\mathrm{H} 3^{\prime}, \mathrm{H} 4},=9.0 \mathrm{~Hz}, J_{\mathrm{H}^{\prime}, \mathrm{H} 5},=9.6 \mathrm{~Hz}\right.$, H-4'), $3.533\left(1 \mathrm{H}, \mathrm{m}, J_{\mathrm{H} 4}{ }^{\prime}, \mathrm{H} 5^{\prime}=9.6 \mathrm{~Hz}, J_{\mathrm{H} 5}{ }^{\prime}, \mathrm{H}^{\prime},=1.8\right.$ $\left.\mathrm{Hz}, J_{\mathrm{H} 5^{\prime}, \mathrm{H} 6^{\prime}}=5.4 \mathrm{~Hz}, \mathrm{H}-5^{\prime}\right), 3.843\left(1 \mathrm{H}, \mathrm{dd}, J_{\mathrm{H} 5^{\prime}, \mathrm{H} 6^{\prime}}=\right.$ $1.8 \mathrm{~Hz}, J_{\mathrm{H} 6}, \mathrm{H} 6^{\prime},=12.6 \mathrm{~Hz}, \mathrm{H}-6$ '), $3.676(1 \mathrm{H}, \mathrm{dd}$,

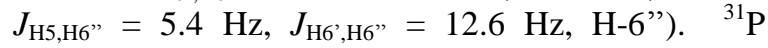
$\operatorname{NMR}\left(\mathrm{D}_{2} \mathrm{O}\right) \delta$ :-15.03 (1P, d, $\left.J_{\mathrm{P}_{\alpha}, \mathrm{P}_{\beta}}=19.2 \mathrm{~Hz}, \mathrm{P}_{\alpha}\right)$, $-21.85\left(1 \mathrm{P}, \mathrm{dd}, J_{\mathrm{P}_{\alpha}, \mathrm{P}_{\beta}}=19.2 \mathrm{~Hz}, J_{\mathrm{P}_{\beta}, \mathrm{P}_{\gamma}}=19.7 \mathrm{~Hz}, \mathrm{P}_{\beta}\right)$, $-6.32\left(1 \mathrm{P}, \mathrm{d}, J_{\mathrm{P}_{\beta}, \mathrm{P}_{\gamma}}=19.7 \mathrm{~Hz}, \mathrm{P}_{\gamma}\right)$.

ESI-MS $m / z$ : 510.98859 Calcd $\left[\mathrm{C}_{12} \mathrm{H}_{19} \mathrm{O}_{16} \mathrm{P}_{3}\right]^{-}$ Found : 510.98222 .

\section{Assignment of 4-triphospho- $\beta$-arbutin}

To identify the 4-triphospho- $\beta$-arbutin in the phosphorylation of $\beta$-arbutin with $\mathrm{P}_{3 \mathrm{~m}}$, the isolation procedure as described above was achieved. As shown in Fig. 3(c), the ${ }^{31} \mathrm{P}$ NMR spectrum with ${ }^{1} \mathrm{H}$ decoupling showed a doublet at $-6.32 \mathrm{ppm}\left(\mathrm{P}_{\gamma}\right)$, a doublet at $-15.03 \mathrm{ppm}\left(\mathrm{P}_{\alpha}\right)$, and a doublet of doublets at $-21.85 \mathrm{ppm}\left(\mathrm{P}_{\beta}\right)$. These peaks are characteristic for triphosphate esters ${ }^{13,14}$. The doublet at -15.03 ppm did not change with ${ }^{1} \mathrm{H}$ non-decoupling in Fig. 3 (b). It indicates that phosphorylation occurs in places not affected by protons ${ }^{15}$. That is, it was presumed that it occurred not on $\beta$-D-glucose moiety but on phenolic $\mathrm{OH}$ group of $\beta$-arbutin. A singlet at $2.19 \mathrm{ppm}$ is assigned to monophosphate $\left(\mathrm{P}_{1}\right)$.

By comparison with Figure 3(a) and 3(b), it found that diphosphate $\left(\mathrm{P}_{2}\right)$, triphosphate $\left(\mathrm{P}_{3}\right)$, and $\mathrm{P}_{3 \mathrm{~m}}$ in the reaction solution were separated after isolation. The purity of product was determined to be $94 \%$ from the integration of ${ }^{31} \mathrm{P}$ NMR signals. The remaining $6 \%$ is the $\mathrm{P}_{1}$ and by-product.

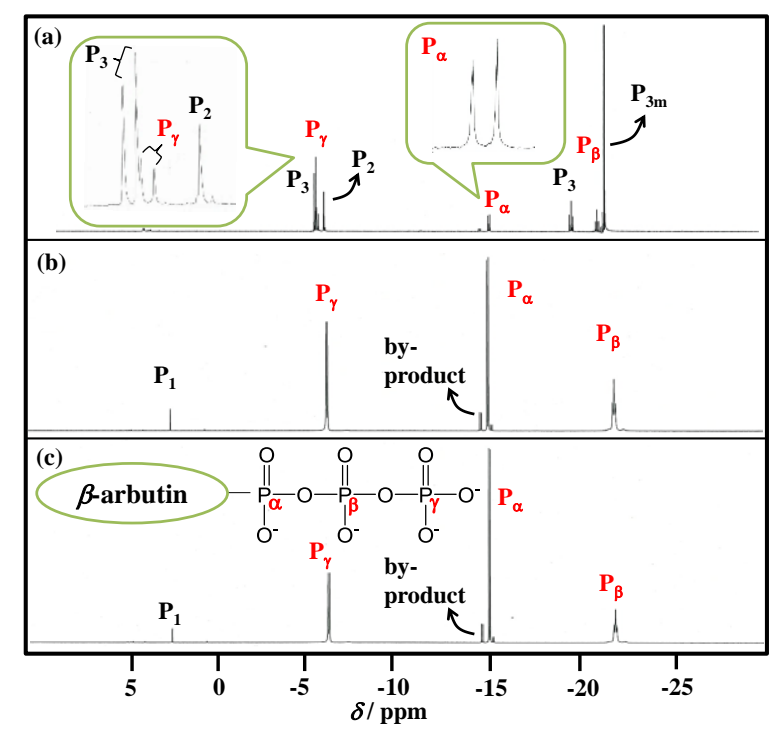

FIGURE $3 \quad{ }^{31} \mathrm{P}$ NMR spectra of reaction solution (a) and isolation product ( $b$ and $c$ )

(a) ${ }^{1} \mathrm{H}$ non-decoupling spectrum of the reaction solution, (b) ${ }^{1} \mathrm{H}$ non-decoupling spectrum of the isolation product, (c) ${ }^{1} \mathrm{H}$ decoupling spectrum of the isolation product

In order to confirm the site of phosphorylation, ${ }^{31} \mathrm{P}-{ }^{1} \mathrm{H}$ heteronuclear multiple bond correlation spectroscopy (HMBC) 2D NMR spectrum was measured. Two correlations of $\mathrm{P}_{\alpha}$ at $-15.03 \mathrm{ppm}$ of product and ${ }^{1} \mathrm{H}$ signal at 7.17 and 7.04 ppm were observed. The multiplets at 7.17 and $7.04 \mathrm{ppm}$ could be assigned to (H-3 and $\mathrm{H}-5)$ and $(\mathrm{H}-2$ and H-6) of the product. The down-field shift from 6.83 and $6.47 \mathrm{ppm}$ due to $\beta$-arbutin itself to 7.17 and 7.04 ppm indicates the phosphorylation of $\beta$-arbutin with $\mathrm{P}_{3 \mathrm{~m}}{ }^{16}$. This assignment was confirmed by ${ }^{1} \mathrm{H}-{ }^{1} \mathrm{H}$ COSY NMR spectrum.

Furthermore, since there were no peaks correspond to $\beta$-arbutin in the ${ }^{1} \mathrm{H}$ NMR data, it could be seen that the raw material was removed by isolation. 


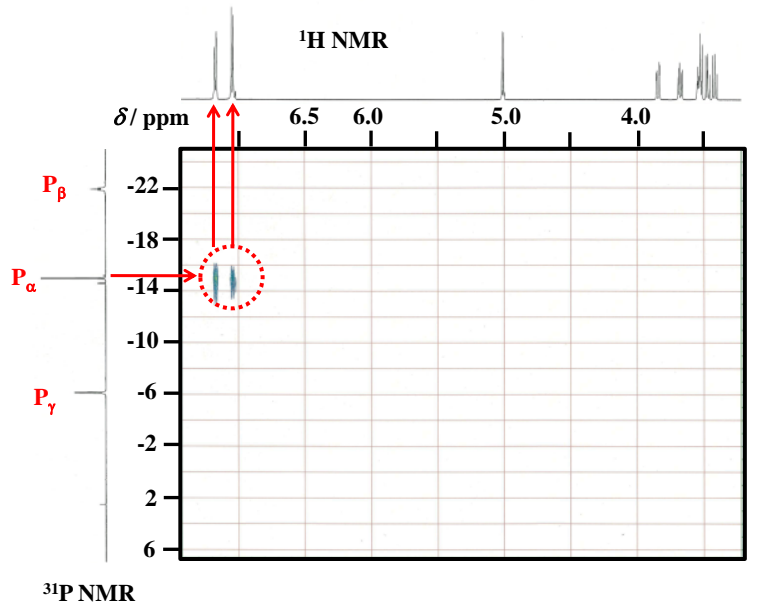

FIGURE $4{ }^{31} \mathrm{P}-{ }^{1} \mathrm{H}$ HMBC $2 \mathrm{D}-\mathrm{NMR}$ spectrum of isolation product

Figure 5 shows ${ }^{1} \mathrm{H}-{ }^{1} \mathrm{H}$ COSY NMR spectra of isolation product. All protons on a $\beta$-D-glucopyranosyl unit will have a correlation with all other protons on the same $\beta$-D-glucopyranosyl unit. Thus, the peak at $5.01,3.84,3.68,3.53,3.53,3.42$, and 3.47 ppm could be assigned to H-1', H-6', H-6", H-3', H-5', H-2' and H-4' proton of $\beta$-D-glucopyranosyl unit, respectively. The chemical shifts of all protons on a $\beta$-D-glucopyranosyl unit did not change before and after phosphorylation. This suggests that $\beta$-D-glucopyranosyl of $\beta$-arbutin have not been phosphorylated. Therefore, we concluded that 4-OH on phenyl group reacted selectively in spite of having five hydroxyl groups.

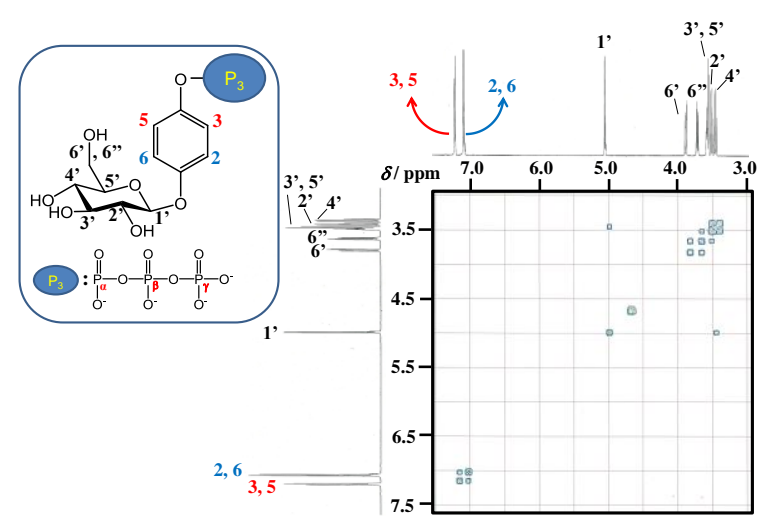

FIGURE $5 \quad{ }^{1} \mathrm{H}-{ }^{1} \mathrm{H}$ COSY NMR spectra of isolation product

In order to confirm, electrospray ionization mass spectrometry (ESI-MS) was performed. The ESI-MS spectrum shows the molecular ion peak due to triphospho- $\beta$-arbutin $(m / z=510.98859)$.

\section{Reaction mechanism of $\beta$-arbutin with $P_{3 m}$}

The reaction of $\beta$-arbutin with $\mathrm{P}_{3 \mathrm{~m}}$ may be explained by the following mechanism. $\mathrm{P}_{3 \mathrm{~m}}$ with six-membered structure consists phosphorus and oxygen atom. Since the electronegativity of oxygen atom is higher than phosphorus atom, the electron pair is attracted to the oxygen atom and the electron density of phosphorus atom becomes smaller and becomes $\mathrm{P}^{\delta+}$. At $\mathrm{pH} 12, \mathrm{P}^{\delta+}$ is easily attacked by nucleophilic reagents such as amino $\operatorname{acid}^{17}$ and alcohol $^{18}$.

In the present study, the lone electron pair on the hydroxyphenyl group of $\beta$-arbutin nucleophilically attacks a phosphorus atom of $\mathrm{P}_{3 \mathrm{~m}}$ to give 4-triphospho- $\beta$-arbutin. The hydroxylphenyl group of $\beta$-arbutin was phosphorylated selectively. Why did not it respond to hydroxyl groups of D-glucopyranosyl unit? The value of $\mathrm{p} K_{1}$ of $\mathrm{D}$-glucose $\mathrm{P}^{19}$ is 12.28 , whereas that of hydroxyphenyl group $^{20}$ is 9.0. Therefore, hydroxylphenyl group of $\beta$-arbutin was phosphorylated selectively.

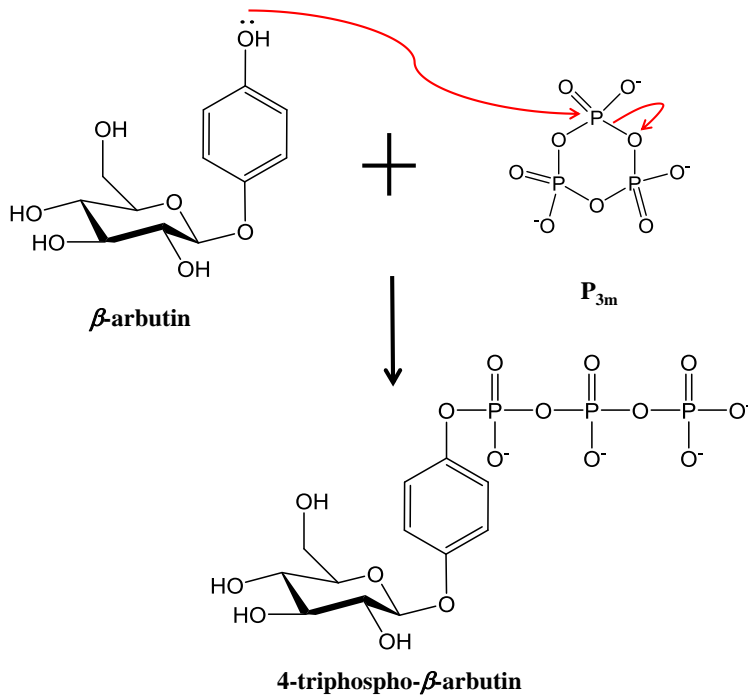

SCHEME $1 \quad$ Reaction of $\beta$-arbutin with $\mathrm{P}_{3 \mathrm{~m}}$

\section{Conclusion}

In the reaction of $\beta$-arbutin with $\mathrm{P}_{3 \mathrm{~m}}$, 4-triphopho- $\beta$-arbutin was synthesized in the yield of $90 \%$. The purity of 4-triphopho- $\beta$-arbutin was determined to be $94 \%$ from the integration of ${ }^{31} \mathrm{P}$ NMR signals. We have successfully introduced the triphosphate group in one molecule. This result suggests that phosphorylated $\beta$-arbutin is expected that the permeability of $\beta$-arbutin into the skin will be increased by introducing a phosphate group. 


\section{ACKNOWLEDGEMENTS}

The authors thank associate professor C. Tode of Kobe Pharmaceutical University for the measurements of ${ }^{31} \mathrm{P},{ }^{31} \mathrm{P}-{ }^{1} \mathrm{H}$ HMBC, ${ }^{1} \mathrm{H}-{ }^{1} \mathrm{H}$ COSY, ${ }^{1} \mathrm{H}-{ }^{1} \mathrm{H}$ TOCSY 2D NMR spectra. This work was partially supported by the Promotion and Mutual Aid Corporation for Private School of Japan.

\section{REFERENCES}

1. The Merck Index 12th ed. Edited by S. Budavari (Merck and Co., Whitehouse Station, N.J., 1996), p. 816.

2. M. Nakajima, I. Shinoda, Y. Fukuwatari, H.

Hayasawa, Pigment Cell Res., 11, 12 (1998).

3. Y-J. Lim, E.H. Lee, T.H. Kang, S.K. Ha, M.S. Oh, S.M. Kim, T-J. Yoon, C. Kang, J-H. Park, S.Y. Kim, Arch. Pharm. Res., 32, 367 (2009).

4. S. Pavez, M. Kang, H-S. Chung, C. Cho, M-C. Hong, M-K. Shin, H. Bae, Phytotherapy Res., 20, 921 (2006).

5. G. Schindler, U. Patzak, B. Brinkhaus, A. von Nieciecki, J. Wittig, N. Kraehmer, I. Gloeckl, M. Veit, J. Clin. Pharmacol., 42, 920 (2002).

6. T.L. Duarte, I.E. Almeida, in Handbook of diet, nutrition and skin. Edited by V.R. Preedy (Springer, Berlin, 2012), pp. 115-127.

7. K. Kameyama, C. Sakai, S. Kondoh, K. Yonemoto, S. Nishiyama, M. Tagawa, T. Murata, T. Ohnuma, J. Quigley, A. Dorsky, D. Bucks, K. Blanock, J. Am. Acad. Dermatol., 34, 29 (1996).

8. S. Kobayashi, M. Takehana, M. Kanke, S. Itoh, E. Ogata, Photochem. Photobiol., 67, 669 (1998).

9. O.T. Quimby, T.J. Flautt, Z. Anorg. Allg. Chem., 296, 220 (1958).

10. H. Maeda, T. Kusuhara, M. Tsuhako, H. Nakayama, Chem. Pharm. Bull., 59 (12), 1447 (2011).

11. H. Maeda, H. Kanazawa, M. Komatsu, H. Nariai, H. Nakayama, Phosphorus Res. Bull., 30, 1 (2015).

12. H. Inoue, M. Watanabe, H. Nakayama, M. Tsuhako, Chem. Pharm. Bull., 48, 802 (2000).

13. H.J. Vogel, in Phosphorous-31 NMR Principles and Applications. Edited by D.G. Gorenstein (Academic Press, New York, 1984), p.114.

14. M. Cohn, T.R. Hughes Jr., J. Biol. Chem., 235, 3250 (1960).

15. H. Inoue, Y. Baba, H. Miyajima, M. Tsuhako, Chem. Pharm. Bull., 40, 3127 (1992).

16. H. Inoue, N. Tone, H. Nakayama, M. Tsuhako, Chem. Pharm. Bull., 50, 1453 (2002).

17. J. Rabinowitz, Helv. Chim. Acta, 52, 2663 (1969).

18. W. Feldmann, Chem. Ber., 100, 3850 (1967).

19. J.A. Dean, in Lange's Handbook of Chemistry 15th ed. Edited by J.A. Dean (McGraw-Hill, New York, 1999), 8.48.
20. The Merck Index 12th ed. Edited by S. Budavari (Merck and Co., Whitehouse Station, N.J., 1996), p. 7390 . 